\title{
Comparison of growth performance and carcass traits of Japanese quails reared in conventional, pasture, and organic conditions
}

\author{
Hakan Inci ${ }^{1}$, Gokce Ozdemir ${ }^{2}$, Bunyamin Sogut ${ }^{1}$, Ahmet Yusuf Sengul' ${ }^{1}$, Turgay Sengul ${ }^{1}$, \\ Mehmet Resit Taysi ${ }^{1}$
}

\author{
${ }^{1}$ Bingol University, Department of Animal Science, Bingol, Turkey. \\ ${ }^{2}$ Bingol University, Faculty of Veterinary Science, Department of Animal Science and Nutrition, Bingol, Turkey.
}

\begin{abstract}
This study was conducted to compare live weight, feed intake, feed conversion, mortality rate, and some carcass characteristics of Japanese quails reared under organic and conventional conditions. A total of 180 one-day-old quail chicks were randomly divided into six groups - Conventional, consuming conventional feed ad libitum; Control (C), consuming organic feed ad libitum; $\mathrm{C}+\mathrm{P}$, consuming organic feed ad libitum + pasture; $80 \mathrm{C}+\mathrm{P}$, consuming $80 \%$ of control + pasture; $70 \mathrm{C}+\mathrm{P}$, consuming $70 \%$ of control + pasture; and $50 \mathrm{C}+\mathrm{P}$, consuming $50 \%$ of control + pasture - with three replicates The conventional group was kept for 6 weeks, while the control, $\mathrm{C}+\mathrm{P}, 80 \mathrm{C}+\mathrm{P}, 70 \mathrm{C}+\mathrm{P}$, and $50 \mathrm{C}+\mathrm{P}$ groups were reared until the end of 10 weeks of age. Raising systems significantly affected live weight, feed intake, and feed conversion. The analysis showed that the meat yield of quail raised in organic conditions had better results than those raised in conventional conditions in terms of appearance, color, aroma, and flavor. The group consuming $50 \%$ of control plus pasture was more advantageous than the other organic groups and the conventional group at the end of the 10 -week fattening period. The organic production system can be a good system to meet the demand of consumers who seek more natural products.
\end{abstract}

Key Words: ad libitum, animal welfare, backyard, organic farming, quail

\section{Introduction}

The reason for the extensive use of conventional confined systems in poultry production is to maximize meat yield and minimize production costs. However, production carried out with this system also brings a number of problems regarding food safety for human health and animal welfare. In the conventional production, using additives or byproducts obtained from the slaughterhouse may cause some health problems for both animals and consumers. Because of these problems, in the last decade, the consumer interest in organic and natural poultry products has been increasing every day, and consequently the organic market has grown by $20 \%$ annually (Fanatico et al., 2005, 2007; Hughner et al., 2007). Besides, free-range rearing systems have received much attention in recent years because of the increasing consumer interest in organic and natural poultry production. Rearing birds in a free-range environment or with outdoor access is accepted as being natural and animal-welfare friendly (Husak et al., 2008). In view of consumer demands,

Received September 1, 2015 and accepted October 26, 2015.

Corresponding author: hakaninci2565@hotmail.com

http://dx.doi.org/10.1590/S1806-92902016000100002

Copyright (c) 2016 Sociedade Brasileira de Zootecnia. This is an Open Access article distributed under the terms of the Creative Commons Attribution License (http://creativecommons.org/licenses/by/4.0/), which permits unrestricted use, distribution, and reproduction in any medium, provided the original work is properly cited. alternative production systems have been developed in the poultry industry; however, these production systems are in a smaller scale and do not endeavor for high efficiency (Dal Bosco et al., 2012). Although there are intermediate systems between conventional and organic productions, the most ideal among the alternative systems is organic production. Organic poultry farming is a production system that uses no synthetically produced feed and chemicals for the nutrition and health-care of the animals, and meets their nutritional and environmental requirements without disturbing their natural behaviors and physiologies (Şahin et al., 2005; Hovi et al., 2003; Herman et al., 2002). In organic poultry production, which has higher standards than other systems, there are quite strict rules regarding feeding and health care protection. However, the cost of organic products is inherently higher and this is reflected in the price.

In some previous studies (Mikulski et al., 2011; Jiang et al., 2011), outdoor access did not change the growth performance of chickens statistically. However, research results (Castellini et al., 2002a; Wang et al., 2009) indicated that the weight gain and feed conversion with the free-range treatment were lower than with the indoor treatment. No significant differences existed in meat yield between conventional and free-range birds (Fanatico et al., 2005; Wang et al., 2009; Jiang et al., 2011), and outdoor access did not have an effect on abdominal fat ratio 
(Grashorn and Brose, 1997; Mikulski et al., 2011). When comparing the meat from broilers raised in organic and conventional systems in terms of flavor and some quality features, consumers found organic poultry to be more savory (MacRae et al., 2007; Yurtseven and Şengül, 2009). In other experiments, meat from slow-growing broilers was tastier than that from fast-growing broilers raised in conventional systems (Culioli et al., 1990; Overbeke et al., 2006; Castellini et al., 2002b).

This study was approved by the Local Ethical Committee on Animal Experiments of Bingol University, dated 05.20.2011, decision No. 2.

Studies on poultry production in organic systems are mostly focused on chickens; however, research on other birds is very limited. This study was conducted to compare the growth performances of carcass traits of Japanese quails raised under organic, pasture, and conventional confinement conditions.

\section{Material and Methods}

A total of 180 one-day-old Japanese quail chicks (Coturnix coturnix japonica) of both sexes were reared in different cages (three replications) under a brooder for the first three weeks of age. Birds were randomly divided into six groups - Conventional, consuming conventional feed ad libitum; Control (C), consuming organic feed ad libitum; $\mathrm{C}+\mathrm{P}$, consuming organic feed ad libitum + pasture; $80 \mathrm{C}+\mathrm{P}$, consuming $80 \%$ of control + pasture; $70 \mathrm{C}+\mathrm{P}$, consuming $70 \%$ of control + pasture; and $50 \mathrm{C}+\mathrm{P}$, consuming $50 \%$ of control + pasture - with three replications, and 10 chicks per pen.

While the conventional group was fattened for $6 \mathrm{wk}$, organic control and pasture groups were fattened for 10 weeks on an indoor-floor system. The other organic groups were raised indoors for the first week, having access to the outdoors for the next nine weeks. The indoor pens had a concrete floor lined with wood shavings measuring $360 \mathrm{~cm}$ $\times 200 \mathrm{~cm} \times 200 \mathrm{~cm}$, and the stocking density was $1.44 \mathrm{~m}^{2} /$ bird . Each indoor pen was connected to an outdoor area that also measured $3 \times 4 \mathrm{~m}\left(1.2 \mathrm{~m}^{2} /\right.$ bird $)$. Indoor and outdoor spaces were separated by a wall with small doors in each pen, through which the quails could freely access the outdoor area. The outdoor ground was similar to the natural environment, with soil and sand floor with vegetation. A metal lattice was used to fence the outdoor area. To prevent the birds from escaping and to avoid predators, the top of the shelters was covered with a special mesh. These shelters were organized considering the conditions that would provide birds free ranging and natural behavior. The birds that were given outdoor access could freely access the outdoor area during the day but were returned to the house at night. The experimental diets were formulated (Table 1) to meet the crude protein (CP) and metabolizable energy (ME) requirements of the birds; an analysis of the diets showed that the $\mathrm{CP}$ and $\mathrm{ME}$ levels matched closely the calculated values. The birds in conventional group were fed a commercial starter diet for the first seven days, and the grower and finisher diets for the following weeks. The treatment groups received

Table 1 - Composition and nutrient content of diets used in the experiment

\begin{tabular}{|c|c|c|c|c|c|c|c|}
\hline \multirow[b]{2}{*}{ Ingredient (\%) } & \multicolumn{3}{|c|}{ Conventional } & \multicolumn{4}{|c|}{ Organic } \\
\hline & $\begin{array}{c}\text { Diet 1 } \\
\text { (weeks 1-2) } \\
(\%)\end{array}$ & $\begin{array}{c}\text { Diet } 2 \\
\text { (weeks 3-5) } \\
(\%)\end{array}$ & $\begin{array}{c}\text { Diet } 3 \\
\text { (week 6) } \\
(\%)\end{array}$ & $\begin{array}{c}\text { Diet } 1 \\
\text { (week 1) } \\
(\%)\end{array}$ & $\begin{array}{c}\text { Diet } 2 \\
\text { (week 2-4) } \\
(\%)\end{array}$ & $\begin{array}{c}\text { Diet } 3 \\
\text { (weeks 5-7) } \\
(\%)\end{array}$ & $\begin{array}{c}\text { Diet } 4 \\
\text { (weeks } 8-10) \\
(\%)\end{array}$ \\
\hline Corn & 55.50 & 61.34 & 65.2 & 52 & 54 & 62 & 65 \\
\hline Soybean meal & 31.28 & 30.7 & 26.64 & 38.7 & 37 & 28.8 & 27.8 \\
\hline Fish meal & 6.0 & - & - & - & 3 & 3 & - \\
\hline Oil & 3.89 & 4.5 & 4.7 & 4 & 3.7 & 3.9 & 4.9 \\
\hline Salt & 0.35 & 0.3 & 0.3 & 0.3 & 0.3 & 0.3 & 0.3 \\
\hline Vitamin-mineral mix ${ }^{1}$ & 0.35 & 0.16 & 0.16 & - & - & - & \\
\hline \multicolumn{8}{|c|}{ Calculated nutrient content (\%) } \\
\hline Metabolizable energy $(\mathrm{kcal} / \mathrm{kg})$ & 3150 & 3146 & 3200 & 3102.8 & 3100 & 3202 & 3280 \\
\hline
\end{tabular}

${ }^{1}$ Added per kg: vit. A - 11.00 IU; vit. D - 32,000 IU; vit. B1 - 2.5 mg; vit. B6 - 1.25 mg; vit. B12 - 0.01 mg; $\alpha$-tocopheryl acetate - 50 mg; biotin - 0.06 mg; vit. K - 2.5 mg; niacin - 15 mg; folic acid - $0.30 \mathrm{mg}$; pantothenic acid - $10 \mathrm{mg}$; choline - $600 \mathrm{mg}$; Mn - $60 \mathrm{mg}$; Fe - $50 \mathrm{mg}$; Zn - $15 \mathrm{mg}$; I - $0.5 \mathrm{mg}$; Co - $0.5 \mathrm{mg}$. 
certified organic feed from beginning to end of the trial. Groups control and $\mathrm{C}+\mathrm{P}$ fed ad libitum. All treatments groups had free outdoor access. Groups $80 \mathrm{C}+\mathrm{P}, 70 \mathrm{C}+\mathrm{P}$, and $50 \mathrm{C}+\mathrm{P}$ received certified organic feed at $80 \%, 70 \%$, and $50 \%$ of what $\mathrm{C}+\mathrm{P}$ consumed, respectively. Raw materials of the organic feed consisted of organically obtained grains and oilseed, which was not treated with chemicals during production-processing stages. Apart from this, premixes that were not organic but permitted for use in organic poultry production were used. All the birds from organic groups consumed same diet, based on certificated corn and soybean meal (IMO Institute Für Marktökologie GmbH-TR-OT-002-Y-0108-732 lot Certifica). Diets were formulated so as to meet the approximate requirements of dry matter, energy, and other nutrients of quails. The nutritional composition of the diets was prepared in accordance with NRC (1994).

Pasture samples were weighed for green herbage yield and were dried at $70{ }^{\circ} \mathrm{C}$ in an oven (Memmert ULM 800) for $24 \mathrm{~h}$ for the hay yield. Dry samples were milled through a 1-mm sieve and used for analysis. The Kjeldahl method was used to determine the nitrogen $(\mathrm{N})$ content of dried samples taken from the plots. Crude protein was calculated by using the equation $\mathrm{N} \times 6.25$ (AOAC, 1990).

Forage samples were transported to the laboratory and oven-dried at $70{ }^{\circ} \mathrm{C}$ for $48 \mathrm{~h}$ to determine dry matter (DM) content. Forage samples were analyzed for ash, and crude protein (CP) according to AOAC (2000).

An IKA brand C200 model bomb calorimeter was used; the device can determine the calorific value in accordance with EN 61010, EN 50082, EN 55014 and EN 60555 standards.

The pasture composition included alfalfa, grass, sainfoin, vetch, wheat, and barley plants. During the grazing season, the nutrient analysis of pasture, on a dry matter basis, had the following results: $14.85,2.4,31.5,9.6,87 \%$ and $1,900 \mathrm{kcal} \mathrm{kg}^{-1}$, for crude protein, crude fat, crude fiber, crude ash, dry matter, and ME, respectively.

A 23-h lighting program was applied for the commercial and control-including groups. The other groups were only exposed to daylight; no additional lighting was applied because the law regulating organic production requires this condition. While the birds in conventional group were slaughtered at the end of $6 \mathrm{wk}$, the other groups were bled at the end of 10 weeks. Fifteen birds with average body weight (BW) were selected from each pen to be slaughtered on $\mathrm{d} 70$ and 42, and the carcass traits were evaluated. Organs were weighed individually. Carcasses were prechilled at $12{ }^{\circ} \mathrm{C}$ for $15 \mathrm{~min}$ and chilled (immersion) at $1{ }^{\circ} \mathrm{C}$ for $45 \mathrm{~min}$. After being chilled, the carcasses were aged at
$1{ }^{\circ} \mathrm{C}$ for $6 \mathrm{~h}$ in a room and separated for their parts. Yields of carcass, breast, back, wings, legs (thighs and drumstick) were recorded (Celik et al., 2014). The carcass weight was calculated by removing the feathers and blood, and the eviscerated weight was calculated by removing the head, feet and organs, except the lungs and kidneys. The carcass yield and eviscerated-carcass yield were then expressed as a percentage of BW. The organs were weighed individually.

A sensory panel test was performed on breast and thigh samples, roasted without salt or spice. The cooked samples were immediately sliced into pieces and randomly offered to 15 trained panelists aged 20 to 40 years. Panelists were seated at different tables in order to prevent interaction with one another, and they were served separate plates. The trial consisted of five sessions, and the following traits were assessed: flavor, aroma, color, appearance, and overall acceptability. A ten-point scale of 1 to 10 was used. Panelists tasted quail meats and evaluated their general appreciations, flavor, aroma, color, and appearance on the distributed forms, by giving a score between 1 and 10 .

The data obtained from this study were subjected to ANOVA by using the GLM procedure of SAS (Statistical Analysis System, version 9.3). To compare significant differences among treatments, means were measured by the Duncan's multiple range tests with a significance limit of $\mathrm{P}<0.05$.

\section{Results and Discussion}

The body weights of the conventional group were significantly higher than those of the organic and pasture groups between the 2 nd and the last weeks of the feeding period (Table 2). While the average $\mathrm{BW}$ of the conventional group was $43.5 \mathrm{~g}(\mathrm{M}+\mathrm{F})$, it varied from 31.5 to $36.8 \mathrm{~g}$ in organic groups. The lowest body weight was observed in control, among the organic treatment groups. At the end of the 4th week, variations between the BW of groups were similar in the 2nd wk; however, quails in the conventional group had higher $(\mathrm{P}<0.01) \mathrm{BW}$. As in organic groups, the male + female $(\mathrm{M}+\mathrm{F})$ from $\mathrm{C}+\mathrm{P}$ group yielded relatively better results concerning BW differences. Birds from the conventional group at 70 days reached the commercial BW satisfactorily. Organic quails, as expected, showed lower growth performance at both ages.

When the organic groups were compared with each other at the 8th and 10th wk of age, at the end of the $10 \mathrm{wk}$ of age, the $\mathrm{C}+\mathrm{P}$ group $(\mathrm{M}+\mathrm{F})$ had significantly $(\mathrm{P}<0.01)$ higher BW than the others, and it was followed by the conventional group. The other three organic groups had similar results. Among the organic groups, the highest BW 
(187.4 g) was observed in group $\mathrm{C}+\mathrm{P}(\mathrm{M}+\mathrm{F})$, and the lowest $(154.2 \mathrm{~g})$ was found in $50 \mathrm{C}+\mathrm{P}$.

In terms of feed intake (Table 3 ), the variation between all groups was significant $(\mathrm{P}<0.01)$ for the $0-4$ week period. In this period, $\mathrm{C}+\mathrm{P}$ consumed the highest amount of feed (456.4 g), followed by the control group. However, the lowest feed intake $(212.0 \mathrm{~g})$ was observed in group $50 \mathrm{C}+\mathrm{P}$. As for the $0-5 \mathrm{wk}$ period, feed intake results were similar to that of the $0-4 \mathrm{wk}$ trial period. A significant variation between groups $(\mathrm{P}<0.01)$ was determined for the 0-6 wk feeding period. While the $\mathrm{C}+\mathrm{P}$ group consumed the highest amount of feed $(855.3 \mathrm{~g})$ in $0-6 \mathrm{wk}$ of age, the $50 \mathrm{C}+\mathrm{P}$ group consumed the lowest amount (395.5 g), as expected. For the $0-8$ week period, organic groups were compared with each other and the variation between averages was significant $(\mathrm{P}<0.01)$. In this period, the $\mathrm{C}+\mathrm{P}$ group had the highest feed intake, followed by the control group. For the 0-10 week period, the variation between the averages of the groups was also significant $(\mathrm{P}<0.01)$ and the $\mathrm{C}+\mathrm{P}$ group had the highest feed intake rates. It was followed by the control, $80 \mathrm{C}+\mathrm{P}, 70 \mathrm{C}+\mathrm{P}$, and $50 \mathrm{C}+\mathrm{P}$ groups, respectively.

Table 2 - Mean body weight (g) of organic and conventional grups at different ages

\begin{tabular}{|c|c|c|c|c|c|c|c|c|c|}
\hline Week & Sex & $\mathrm{n}$ & Conventional & Control & $\mathrm{C}+\mathrm{P}$ & $80 \mathrm{C}+\mathrm{P}$ & $70 \mathrm{C}+\mathrm{P}$ & $50 \mathrm{C}+\mathrm{P}$ & Significance \\
\hline 0 & $\mathrm{M}+\mathrm{F}$ & & $8.3 \pm 1.2$ & $8.5 \pm 1.2$ & $8.4 \pm 1.2$ & $8.3 \pm 1.2$ & $8.4 \pm 1.2$ & $8.4 \pm 1.2$ & NS \\
\hline \multirow{2}{*}{2} & M & 15 & $43.1 \pm 1.9 \mathrm{a}$ & $30.1 \pm 1.9 \mathrm{c}$ & $36.2 \pm 1.3 b$ & $33.2 \pm 1.3 b$ & $34.2 \pm 1.3 b$ & $35.2 \pm 1.6 \mathrm{~b}$ & * \\
\hline & $\mathrm{M}+\mathrm{F}$ & 30 & $43.5 \pm 1.6 \mathrm{a}$ & $31.5 \pm 1.6 \mathrm{c}$ & $35.8 \pm 1.1 \mathrm{~b}$ & $34.8 \pm 1.5 b$ & $35.6 \pm 1.3 \mathrm{~b}$ & $36.8 \pm 1.3 \mathrm{~b}$ & $*$ \\
\hline 4 & M & 15 & $129.2 \pm 5.0 \mathrm{a}$ & $70.9 \pm 3.0 \mathrm{c}$ & $78.5 \pm 2.6 b c$ & $63.8 \pm 2.8 \mathrm{c}$ & $68.0 \pm 3.6 \mathrm{c}$ & $62.8 \pm 3.0 \mathrm{c}$ & $* *$ \\
\hline \multirow{3}{*}{6} & M & 15 & $154.3 \pm 7.1 \mathrm{a}$ & $92.4 \pm 7.1 \mathrm{c}$ & $119.3 \pm 3.0 \mathrm{~b}$ & $103.1 \pm 7.1 \mathrm{c}$ & $97.0 \pm 7.1 \mathrm{c}$ & $98.3 \pm 7.1 \mathrm{c}$ & $* *$ \\
\hline & $\mathrm{F}$ & 15 & $195.5 \pm 5.2 \mathrm{a}$ & $117.2 \pm 1.2 \mathrm{c}$ & $136.6 \pm 4.8 \mathrm{~b}$ & $110.2 \pm 5.2 \mathrm{c}$ & $116.8 \pm 2.2 \mathrm{c}$ & $112.4 \pm 5.2 \mathrm{c}$ & $* *$ \\
\hline & $\mathrm{M}+\mathrm{F}$ & 30 & $175.4 \pm 6.2 \mathrm{a}$ & $104.8 \pm 6.2 \mathrm{c}$ & $127.5 \pm 2.8 b$ & $107.6 \pm 1.2 \mathrm{c}$ & $106.5 \pm 1.2 \mathrm{c}$ & $105.4 \pm 2.2 \mathrm{c}$ & $* *$ \\
\hline 8 & M & 15 & & $129.6 \pm 5.1 \mathrm{a}$ & $138.7 \pm 3.0 \mathrm{~b}$ & $121.2 \pm 5.1 \mathrm{c}$ & $124.8 \pm 4.1 \mathrm{ac}$ & $117.2 \pm 4.1 \mathrm{ac}$ & $* *$ \\
\hline \multirow[t]{2}{*}{10} & $\mathrm{~F}$ & 15 & & $184.6 \pm 4.8 \mathrm{a}$ & $200.0 \pm 6.2 b$ & $173.0 \pm 4.2 \mathrm{c}$ & $172.1 \pm 3.8 \mathrm{c}$ & $164.8 \pm 5.2 \mathrm{~d}$ & $* *$ \\
\hline & $\mathrm{M}+\mathrm{F}$ & 30 & & $174.2 \pm 4.6 \mathrm{a}$ & $187.4 \pm 4.6 \mathrm{~b}$ & $162.9 \pm 4.1 \mathrm{c}$ & $164.4 \pm 3.9 \mathrm{c}$ & $154.2 \pm 4.1 \mathrm{~d}$ & $* *$ \\
\hline
\end{tabular}

Treatments: Conventional - conventional feed ad libitum; Control - organic feed ad libitum; $\mathrm{C}+\mathrm{P}-$ organic feed ad libitum + pasture; $80 \mathrm{C}+\mathrm{P}-80 \%$ of control + pasture; $70 \mathrm{C}+\mathrm{P}-70 \%$ of control + pasture; $50 \mathrm{C}+\mathrm{P}-50 \%$ of control + pasture.

Mean \pm standard deviation.

a, b, c - differences between means in the same row with different letters are significant.

NS - not significant; $* \mathrm{P}<0.05 ; * * \mathrm{P}<0.01$.

$\mathrm{M}$ - male; F - female; $\mathrm{M}+\mathrm{F}$ - mixed (male + female)

Table 3 - Intake of feed with supplements, feed conversion rates, and standard errors of the control and treatment groups

\begin{tabular}{|c|c|c|c|c|c|c|c|}
\hline Weeks & Conventional & Control & $\mathrm{C}+\mathrm{P}$ & $80 \mathrm{C}+\mathrm{P}$ & $70 \mathrm{C}+\mathrm{P}$ & $50 \mathrm{C}+\mathrm{P}$ & Significance \\
\hline \multicolumn{8}{|c|}{ Feed intake $(\mathrm{g})$} \\
\hline $0-4$ & $406.6 \pm 7.2 \mathrm{bc}$ & $424.3 \pm 6.4 b$ & $456.4 \pm 6.4 \mathrm{a}$ & $339.4 \pm 6.4 \mathrm{~d}$ & $298.9 \pm 6.4 \mathrm{e}$ & $212.0 \pm 6.4 \mathrm{f}$ & $* *$ \\
\hline $0-5$ & $569.3 \pm 9.2 \mathrm{bc}$ & $599.3 \pm 9.2 b$ & $648.4 \pm 9.2 \mathrm{a}$ & $479.4 \pm 9.2 d$ & $419.3 \pm 9.2 \mathrm{e}$ & $299.7 \pm 9.2 f$ & $* *$ \\
\hline $0-8$ & - & $1003.8 \pm 8.2 \mathrm{ab}$ & $1085.7 \pm 9.0 \mathrm{a}$ & $785.0 \pm 8.2 \mathrm{c}$ & $702.1 \pm 9.0 \mathrm{dc}$ & $501.5 \pm 9.0 \mathrm{e}$ & $* *$ \\
\hline $0-10$ & - & $1268.3 \pm 1.2 \mathrm{ab}$ & $1310.9 \pm 1.4 \mathrm{a}$ & $980.6 \pm 1.6 \mathrm{c}$ & $880.6 \pm 1.2 \mathrm{~d}$ & $600.8 \pm 1.6 \mathrm{e}$ & $* *$ \\
\hline \multicolumn{8}{|c|}{ Feed conversion ratio $(\mathrm{g} / \mathrm{g})$} \\
\hline $0-5$ & $3.6 \pm 0.6 \mathrm{a}$ & $6.7 \pm 0.6 \mathrm{~b}$ & $5.7 \pm 0.6 \mathrm{c}$ & $5.5 \pm 0.6 \mathrm{c}$ & $4.3 \pm 0.6 \mathrm{ac}$ & $3.5 \pm 0.6 \mathrm{a}$ & $* *$ \\
\hline $0-6$ & $4.3 \pm 0.9 \mathrm{a}$ & $6.8 \pm 0.9 b$ & $6.7 \pm 0.9 b$ & $6.2 \pm 0.9 \mathrm{~b}$ & $4.8 \pm 0.9 \mathrm{a}$ & $3.8 \pm 0.9 \mathrm{c}$ & $* *$ \\
\hline $0-8$ & - & $6.8 \pm 1.0 \mathrm{a}$ & $6.8 \pm 1.0 \mathrm{a}$ & $6.2 \pm 1.0 \mathrm{a}$ & $5.3 \pm 1.4 \mathrm{~b}$ & $4.0 \pm 1.4 \mathrm{c}$ & $* *$ \\
\hline $0-10$ & - & $6.8 \pm 1.5 \mathrm{a}$ & $7.0 \pm 0.9 \mathrm{a}$ & $6.0 \pm 1.4 \mathrm{~b}$ & $5.3 \pm 1.1 \mathrm{c}$ & $4.1 \pm 1.1 \mathrm{~d}$ & $* *$ \\
\hline
\end{tabular}

Treatments: Conventional - conventional feed ad libitum; Control - organic feed ad libitum $; \mathrm{C}+\mathrm{P}-$ organic feed ad libitum + pasture; $80 \mathrm{C}+\mathrm{P}-80 \%$ of control + pasture; $70 \mathrm{C}+\mathrm{P}-70 \%$ of control + pasture; $50 \mathrm{C}+\mathrm{P}-50 \%$ of control + pasture.

Mean \pm standard deviation.

$\mathrm{a}, \mathrm{b}, \mathrm{c}, \mathrm{d}, \mathrm{e}, \mathrm{f}-$ differences between means in the same row with different letters are significant $(\mathrm{P}<0.01)$

NS - not significant; ** $\mathrm{P}<0.01$. 
Regarding the feed conversion (FC), the variation between groups was significant $(\mathrm{P}<0.01)$ for the $0-4 \mathrm{wk}$ period. In this period, the conventional group had the highest $\mathrm{FC}$, and then the $50 \mathrm{C}+\mathrm{P}$ group followed it. As for the $0-5$ wk period, the $50 \mathrm{C}+\mathrm{P}$ organic group and the conventional group gave the best results. Compared with the other groups, those two groups had significantly better conversion rates. Similarly, a significant variation between groups was determined $(\mathrm{P}<0.01)$ in the $0-6$ wk period. The $50 \mathrm{C}+\mathrm{P}$ group had the best $\mathrm{FC}$, with 3.8 , whereas the control and $\mathrm{C}+\mathrm{P}$ groups had the worst values: 6.8 and 6.7, respectively.

In terms of $\mathrm{FC}$, significant $(\mathrm{P}<0.01)$ differences among the means were determined for the $0-8$ wk period in organic groups. In this period, the $50 \mathrm{C}+\mathrm{P}$ group had the best $(\mathrm{P}<0.01) \mathrm{FC}$, while the conventional and $\mathrm{C}+\mathrm{P}$ groups had the worst. In the $0-10 \mathrm{wk}$ period, variations between the means of the groups were also significant $(\mathrm{P}<0.01)$ and the $50 \mathrm{C}+\mathrm{P}$ group had the best $\mathrm{FC}$, with 4.1

Significant differences $(\mathrm{P}<0.01)$ for average carcass weight, carcass yield, thigh weight, and breast weight
(Table 4) were observed among the groups in both male and female. The highest carcass weight for $\mathrm{M}+\mathrm{F}$ was obtained by the $\mathrm{C}+\mathrm{P}$ group (127.5 g), while the lowest value was found in $80 \mathrm{C}+\mathrm{P}(114.5 \mathrm{~g})$. However, the dressing percentage for $\mathrm{M}+\mathrm{F}$ in $50 \mathrm{C}+\mathrm{P}$ was the highest, $74.7 \%$, followed by $70 \mathrm{C}+\mathrm{P}$, with $72.4 \%$. With regard to average thigh weight, the $\mathrm{C}+\mathrm{P}$ group had the highest values $(34.7 \mathrm{~g})$.

Variations in the liver and thigh weights (except for females) between groups were significant $(\mathrm{P}<0.05)$. For heart weight, the variation between the conventional and organic groups was not significant.

According to the results of the sensory analysis (Table 5), rather than those reared in conventional conditions, panelists preferred the meat from birds reared organically. Cooked meat from the organic system was determined to be preferable when the evaluation involved appearance, color, aroma, and flavor $(\mathrm{P}<0.05, \mathrm{P}<0.01)$.

According to previous studies (Mikulski et al., 2011; Jiang et al., 2011), outdoor access did not change the growth performance of chickens statistically. However, researchers (Castellini et al., 2002a; Wang et al., 2009)

Table 4 - Comparison of the average carcass characteristics of conventional (6 weeks) and organic (10 weeks) groups

\begin{tabular}{|c|c|c|c|c|c|c|c|c|}
\hline Trait & Sex & Conventional & Control & $\mathrm{C}+\mathrm{P}$ & $80 \mathrm{C}+\mathrm{P}$ & $70 \mathrm{C}+\mathrm{P}$ & $50 \mathrm{C}+\mathrm{P}$ & Significance \\
\hline \multirow{3}{*}{ Carcass weight, $\mathrm{g}$} & M & $109.3 \pm 6.8 \mathrm{a}$ & $116.3 \pm 6.8 b$ & $127.5 \pm 5.6 \mathrm{c}$ & $107.2 \pm 5.3 \mathrm{a}$ & $113.7 \pm 4.6 \mathrm{ab}$ & $109.6 \pm 7.5 \mathrm{a}$ & $* *$ \\
\hline & $\mathrm{F}$ & $138.4 \pm 6.8 \mathrm{a}$ & $132.9 \pm 5.9 \mathrm{a}$ & $144.2 \pm 4.3 \mathrm{c}$ & $122.6 \pm 5.1 d$ & $125.4 \pm 4.8 \mathrm{~d}$ & $120.8 \pm 5.1 \mathrm{~d}$ & $* *$ \\
\hline & $\mathrm{M}+\mathrm{F}$ & $122.8 \pm 6.4 \mathrm{a}$ & $123.5 \pm 5.4 \mathrm{a}$ & $133.9 \pm 4.7 b$ & $114.5 \pm 4.1 \mathrm{c}$ & $119.2 \pm 5.4 \mathrm{ac}$ & $115.2 .2 \pm 5.8 \mathrm{a}$ & $* *$ \\
\hline \multirow{3}{*}{ Carcass yield, \% } & M & $70.9 \pm 0.1 \mathrm{a}$ & $71.0 \pm 0.1 \mathrm{a}$ & $72.9 \pm 0.0 \mathrm{~b}$ & $70.5 \pm 0.1 \mathrm{a}$ & $72.5 \pm 0.1 \mathrm{~b}$ & $76.0 \pm 0.1 \mathrm{~b}$ & $* *$ \\
\hline & $\mathrm{F}$ & $71.0 \pm 0.1 \mathrm{a}$ & $72.0 \pm 0.1 \mathrm{a}$ & $72.1 \pm 0.0 \mathrm{a}$ & $70.9 \pm 0.0 \mathrm{a}$ & $72.9 \pm 0.1 b$ & $73.5 \pm 0.1 b$ & $* *$ \\
\hline & $\mathrm{M}+\mathrm{F}$ & $70.0 . \pm 0.1 \mathrm{a}$ & $70.9 \pm 0.1 \mathrm{a}$ & $72.1 \pm 0.1 b$ & $70.3 \pm 0.0 \mathrm{a}$ & $72.4 \pm 0.1 b$ & $73.6 \pm 0.1 \mathrm{c}$ & $* *$ \\
\hline \multirow{3}{*}{ Breast weight, $\mathrm{g}$} & M & $31.4 \pm 1.5 \mathrm{ab}$ & $29.7 \pm 1.1 \mathrm{a}$ & $33.0 \pm 1.1 \mathrm{~b}$ & $28.6 \pm 1.4 \mathrm{a}$ & $29.0 \pm 1.2 \mathrm{a}$ & $28.9 \pm 1.5 \mathrm{a}$ & $* *$ \\
\hline & $\mathrm{F}$ & $35.8 \pm 1.7 \mathrm{ab}$ & $34.3 \pm 1.6 \mathrm{a}$ & $36.4 \pm 1.6 \mathrm{~b}$ & $31.7 \pm 1.8 \mathrm{c}$ & $33.8 \pm 1.6 \mathrm{a}$ & $35.4 \pm 1.5 \mathrm{ab}$ & $* *$ \\
\hline & $\mathrm{M}+\mathrm{F}$ & $33.7 \pm 2.1 \mathrm{ab}$ & $32.0 \pm 2.4 \mathrm{a}$ & $34.7 \pm 1.9 b$ & $30.2 \pm 1.6 \mathrm{c}$ & $31.4 \pm 1.5 \mathrm{a}$ & $32.2 \pm 1.5 \mathrm{a}$ & $* *$ \\
\hline \multirow{3}{*}{ Breast ratio, $\%$} & M & $28.9 \pm 1.5 \mathrm{a}$ & $25.6 \pm 1.9 \mathrm{a}$ & $25.9 \pm 2.1 \mathrm{a}$ & $26.7 \pm 3.0 \mathrm{a}$ & $25.5 \pm 2.1 \mathrm{a}$ & $26.3 \pm 2.2 \mathrm{a}$ & NS \\
\hline & $\mathrm{F}$ & $25.9 \pm 2.1 \mathrm{a}$ & $25.8 \pm 2.5 \mathrm{a}$ & $25.2 \pm 2.5 \mathrm{a}$ & $25.9 \pm 2.5 \mathrm{a}$ & $26.9 \pm 2.1 \mathrm{a}$ & $29.0 \pm 2.5 \mathrm{a}$ & NS \\
\hline & $\mathrm{M}+\mathrm{F}$ & $27.5 \pm 1.4 \mathrm{a}$ & $25.9 \pm 2.4 \mathrm{a}$ & $25.9 \pm 2.4 \mathrm{a}$ & $26.4 \pm 2.4 \mathrm{a}$ & $26.3 \pm 2.2 \mathrm{a}$ & $27.6 \pm 2.4 \mathrm{a}$ & NS \\
\hline \multirow{3}{*}{ Drumstick weight, $\mathrm{g}$} & M & $40.9 \pm 2.1 \mathrm{a}$ & $41.6 \pm 2.5 \mathrm{ab}$ & $43.4 \pm 3.1 b$ & $39.3 \pm 2.5 \mathrm{a}$ & $42.2 \pm 2.4 \mathrm{ab}$ & $41.5 \pm 3.3 b$ & $* *$ \\
\hline & $\mathrm{F}$ & $49.7 \pm 2.1 \mathrm{a}$ & $46.3 \pm 2.1 b$ & $52.5 \pm 2.3 \mathrm{a}$ & $46.3 \pm 2.1 b$ & $46.2 \pm 2.1 \mathrm{~b}$ & $46.9 \pm 2.1 \mathrm{a}$ & $* *$ \\
\hline & $\mathrm{M}+\mathrm{F}$ & $46.1 \pm 3.3 \mathrm{a}$ & $43.7 \pm 2.1 b$ & $47.8 \pm 2.9 \mathrm{a}$ & $43.2 \pm 3.3 b$ & $44.0 \pm 2.9 b$ & $44.2 \pm 2.9 \mathrm{a}$ & $* *$ \\
\hline \multirow{3}{*}{ Drumstick ratio, $\%$} & M & $37.5 \pm 1.6 \mathrm{a}$ & $35.8 \pm 1.6 \mathrm{a}$ & $34.0 \pm 1.3 b$ & $36.6 \pm 1.7 \mathrm{a}$ & $37.1 \pm 1.3 \mathrm{a}$ & $37.1 \pm 1.6 \mathrm{a}$ & NS \\
\hline & $\mathrm{F}$ & $36.0 \pm 1.8 \mathrm{ab}$ & $35.1 \pm 1.4 b$ & $36.4 \pm 1.6 \mathrm{ab}$ & $37.7 \pm 1.8 \mathrm{a}$ & $36.8 \pm 1.7 \mathrm{ab}$ & $38.5 \pm 1.4 \mathrm{a}$ & $*$ \\
\hline & $\mathrm{M}+\mathrm{F}$ & $37.6 \pm 2.1 \mathrm{a}$ & $35.4 \pm 2.4 \mathrm{ab}$ & $35.7 \pm 1.9 \mathrm{ab}$ & $37.9 \pm 1.8 \mathrm{a}$ & $37.0 \pm 1.5 \mathrm{a}$ & $37.4 \pm 1.5 \mathrm{a}$ & $*$ \\
\hline \multirow{3}{*}{ Heart weight, g } & M & $1.2 \pm 0.1 \mathrm{a}$ & $1.3 \pm 0.1 \mathrm{a}$ & $1.1 \pm 0.1 \mathrm{a}$ & $1.1 \pm 0.1 \mathrm{a}$ & $1.2 \pm 0.1 \mathrm{a}$ & $1.2 \pm 0.1 \mathrm{a}$ & NS \\
\hline & $\mathrm{F}$ & $1.3 \pm 0.1 \mathrm{a}$ & $1.3 \pm 0.1 \mathrm{a}$ & $1.3 \pm 0.1 \mathrm{a}$ & $1.3 \pm 0.1 \mathrm{a}$ & $1.3 \pm 0.1 \mathrm{a}$ & $1.3 \pm 0.1 \mathrm{a}$ & NS \\
\hline & $\mathrm{M}+\mathrm{F}$ & $1.2 \pm 0.1 \mathrm{a}$ & $1.3 \pm 0.1 \mathrm{a}$ & $1.2 \pm 0.1 \mathrm{a}$ & $1.2 \pm 0.1 \mathrm{a}$ & $1.2 \pm 0.1 \mathrm{a}$ & $1.2 \pm 0.1 \mathrm{a}$ & NS \\
\hline \multirow{3}{*}{ Liver weight, g } & M & $3.1 \pm 0.3 \mathrm{ab}$ & $3.8 \pm 0.3 b$ & $2.8 \pm 0.3 \mathrm{a}$ & $2.8 \pm 0.3 \mathrm{a}$ & $3.8 \pm 0.3 b$ & $3.4 \pm 0.3 \mathrm{ab}$ & $*$ \\
\hline & $\mathrm{F}$ & $4.9 \pm 0.3 \mathrm{a}$ & $5.0 \pm 0.3 \mathrm{a}$ & $4.0 \pm 0.3 \mathrm{ab}$ & $3.2 \pm 0.3 b$ & $4.3 \pm 0.3 \mathrm{ab}$ & $4.8 \pm 0.3 \mathrm{a}$ & $*$ \\
\hline & $\mathrm{M}+\mathrm{F}$ & $3.9 \pm 0.2 \mathrm{ab}$ & $4.4 \pm 0.2 b$ & $3.4 \pm 0.2 \mathrm{a}$ & $3.0 \pm 0.2 \mathrm{a}$ & $4.1 \pm 0.2 \mathrm{ab}$ & $3.7 \pm 0.2 \mathrm{ab}$ & $*$ \\
\hline
\end{tabular}

Treatments: Conventional - conventional feed ad libitum; Control - organic feed ad libitum $; \mathrm{C}+\mathrm{P}$ - organic feed ad libitum + pasture; $80 \mathrm{C}+\mathrm{P}-80 \%$ of control + pasture; $70 \mathrm{C}+\mathrm{P}-70 \%$ of control + pasture; $50 \mathrm{C}+\mathrm{P}-50 \%$ of control + pasture.

Mean \pm standard deviation.

$\mathrm{a}, \mathrm{b}, \mathrm{c}$ - differences between means in the same row with different letters are significant.

$\mathrm{M}$ - male; $\mathrm{F}$ - female; $\mathrm{M}+\mathrm{F}$ - mixed (male + female).

NS - not significant; * $\mathrm{P}<0.05 ; * * \mathrm{P}<0.01$. 
Table 5 - Results of sensory analysis of cooked meat of quails raised in organic and conventional systems and standard errors

\begin{tabular}{lcccccc}
\hline \multirow{2}{*}{ Trait } & \multicolumn{2}{c}{ Organic } & & \multicolumn{2}{c}{ Conventional } & \multirow{2}{*}{ Significance } \\
\cline { 2 - 3 } \cline { 6 - 7 } & $\mathrm{n}$ & $\mathrm{X} \pm \mathrm{Sx}$ & & $\mathrm{n}$ & $\mathrm{X} \pm \mathrm{Sx}$ & \\
\hline Appearance & 15 & $7.9 \pm 0.24 \mathrm{a}$ & & 15 & $7.4 \pm 0.61 \mathrm{~b}$ & $*$ \\
Color & 15 & $7.5 \pm 0.31 \mathrm{a}$ & & 15 & $7.1 \pm 0.32 \mathrm{~b}$ & $*$ \\
Smell & 15 & $7.4 \pm 0.19 \mathrm{a}$ & & 15 & $6.9 \pm 0.43 \mathrm{~b}$ & $*$ \\
Taste & 15 & $8.6 \pm 0.21 \mathrm{a}$ & & 15 & $7.5 \pm 0.30 \mathrm{~b}$ & $* *$ \\
Overall rating & 15 & $8.5 \pm 0.28 \mathrm{a}$ & & 15 & $8.0 \pm 0.40 \mathrm{~b}$ & $*$ \\
\hline
\end{tabular}

Mean \pm standard deviation.

$\mathrm{a}, \mathrm{b}$ - differences between means in the same row with different letters are significant.

$* \mathrm{P}<0.05 ; * * \mathrm{P}<0.01$.

have reported that the weight gain and FC in the free-range treatment were lower than with the indoor treatment. The performance of birds reared outdoors could be influenced by many uncontrolled factors such as exercise, temperature, light density, and especially pasture intake, which might contribute with some nutrients and interfere with the normal feed intake of quails, consequently impairing growth performance. Birds in the outdoor treatment were confined within the indoor pens at night to be protected from predators. All these factors maintained the growth performance of outdoor birds in the normal range just as the indoor birds. The carcass and parts yields were influenced by the outdoor access, agreeing with previous findings (Fanatico et al., 2005; Wang et al., 2009; Jiang et al., 2011), and demonstrated that no difference existed in meat yield between conventional and free-range birds. Studies have also reported that outdoor access did not have effects on abdominal fat ratio (Grashorn and Brose, 1997; Mikulski et al., 2011). Conventional birds may have reached their full potential in breast yield to satisfy consumer demands and achieve maximum profitability. Researchers (MacRae et al., 2007; Yurtseven and Sengul, 2009) have reported that when comparing the meat from broilers raised in organic and conventional systems in terms of taste and some quality features, consumers found organic poultry to be more savory and have a higher quality. Culioli et al. (1990), Overbeke et al. (2006), and Castellini et al. (2002b) stated that the meat from chicken in organic systems and meat from slow-growing broilers were tastier than that from fastgrowing broilers raised in conventional systems. The impact of farming based on free ranging was not significant on growth performance or carcass yield, but had a significant effect on meat quality (Chen et al., 2013).

When the average BW of the groups was compared, the conventional group had a significantly higher BW for the first six weeks of the fattening period. However, in terms of feed intake, the conventional group consumed more feed than the organic groups, except $\mathrm{C}+\mathrm{P}$ in $0-6$ weeks. This is an expected result for the conventional group, as they were continuously kept indoors and were not allowed access to pasture. The results of this study agree with those reported by Bassler (2005) and Moujahed and Haddad (2013). Feed intake by the conventional group was also high because these animals were not allowed access to pasture, similarly to the conventional group. However, the $\mathrm{C}+\mathrm{P}$ group consumed much more feed than the other organic groups $(\mathrm{P}<0.01)$. Feed intake is expected to be lower for the duration of the fattening period for groups $80 \mathrm{C}+\mathrm{P}, 70 \mathrm{C}+\mathrm{P}$, and $50 \mathrm{C}+\mathrm{P}$, which were allowed access to pasture. The reason for this lower feed intake is the feed restriction at different levels and the free access to pasture.

There was no significant difference for the $\mathrm{BW}$ of the organic groups from the beginning to the end of seven weeks of age; however, $\mathrm{C}+\mathrm{P}$ had a higher $\mathrm{BW}$ than the other groups at the 8th and 9th wk. At the end of the tenth week, the feed intake of both groups was significantly higher than that of the others. The amount of feed consumed by the $\mathrm{C}+\mathrm{P}$ group was more than twice as that of the $50 \mathrm{C}+\mathrm{P}$ group. In free-pasture groups, feed intake decreased proportionately to the increase in feed restriction. Considering the $\mathrm{FC}$ of the groups in 0-6 wk of age, $50 \mathrm{C}+\mathrm{P}$ was the best, followed by the conventional and $70 \mathrm{C}+\mathrm{P}$ groups, respectively. Similar results for FC were also observed in the $0-8$ wk of age, whereas in the $0-10 \mathrm{wk}$ of age, the $50 \mathrm{C}+\mathrm{P}$ group had the best $\mathrm{FC}$, followed by groups $70 \mathrm{C}+\mathrm{P}$ and $80 \mathrm{C}+\mathrm{P}$, respectively. The obtained results are in line with those of Castellini et al. (2002a). The feed intake of the conventional group at 6 weeks was $20 \%$ higher than that of group $50 \mathrm{C}+\mathrm{P}$ at 10 weeks. Therefore, considering the feed costs, it is possible to say that the $50 \mathrm{C}+\mathrm{P}$ had the lowest feed intake and the best FC. The obtained results are similar to those of Castellini et al. (2002a) and Söğüt et al. (2011), who studied conventional and organic broiler production. In a research study, Söğüt et al. (2011) reported that 50 and 70\% feed restriction for broiler affected growth performance positively. Petek et al. (2004) reported that free ranging plays an active role in physical activity and leg conditions for organically raised broilers.

Significant differences in almost all characteristics except for heart weight were determined when the groups were compared with respect to carcass weight, carcass yield, and average weights of carcass parts and edible organs. For carcass weight $(\mathrm{M}+\mathrm{F})$, all groups except $\mathrm{C}+\mathrm{P}$ showed similar values to those of the conventional group. The results of this study were similar to the findings of Castellini et al. (2002a) and Bassler (2005). Organic groups were generally observed to provide higher carcass yield rates 
$(\mathrm{M}+\mathrm{F})$. However, regarding the weight of carcass parts and internal organs, the conventional group had higher values than the organic groups. According to Lei and Van Beek (1997), organic production generally yielded higher breast meat and that resulted from higher $\mathrm{O}_{2}$ requirement and increased respiration, because animals were let outdoors and were able to roam more. A study on the meat quality of broilers in organic and conventional systems (Küçükyılmaz et al., 2009) reported that the impact of the raising system was insignificant on carcass yield, but significant on breast and back ratios.

Mortality rates were found to be $0,5,3.3,3.3,3.3$, and $0 \%$ for the conventional, organic, $\mathrm{C}+\mathrm{P}, 80 \mathrm{C}+\mathrm{P}, 70 \mathrm{C}+\mathrm{P}$, and $50 \mathrm{C}+\mathrm{P}$ groups, respectively. Mortality rates were within normal limits in other free-pasture groups. The mortality rate was reported to be less than 5\% in some studies on organic broiler raising (Lewis et al., 1997; Castellini et al., 2002a; Fanatico, 2006; Dou et al., 2009; Mikulski et al., 2011).

\section{Conclusions}

The indoors ad libitum feeding practice with organic feed is not advantageous in organic quail production; however, organic feed ad libitum + pasture systems are more suitable. On the other hand, in terms of feed conversion and feed intake, the best organic production system is that with $50 \%$ organic feed + pasture. When the price of quail meat is considered, organic meat is three times more expensive than the conventional type. For this reason, organic production is better than conventional production. In addition, because quails are generally sold by whole carcass instead of by carcass weight, $50 \%$ organic feed + pasture could be more profitable and the best practice in organic production.

\section{Acknowledgments}

The authors wish to thank the Research Fund of Bingol University for providing financial support (Project \# 2010-10), and the facility used in this experiment.

\section{References}

AOAC - Association of Official Analytical Chemists. 1990. Official method of analysis. 15th. ed. Association of Official Analytical Chemist, Washington, DC, USA.

AOAC - Association of Official Analytical Chemists. 2000. Official methods of analysis. Association of Official Analytical Chemists, Gaithersburg, MD, USA.

Bassler, A. W. 2005. Organic broilers in floorless pens on pasture. Doctoral thesis. Swedish University of Agricultural Sciences, Uppsala.
Chen, X.; Jiang, W.; Tan, H. Z.; Xu, G. F.; Zhang, X. B.; Wei, S. and Wang, X. Q. 2013. Effects of outdoor access on growth performance, carcass composition, and meat characteristics of broiler chickens. Poultry Science 92:435-443.

Castellini, C.; Dal Bosco, A. and Mugnai, C. 2002a. Effect on conventional versus organic method of production on the broiler carcass and meat quality. Meat Science 60:219-224.

Castellini, C.; Mugnai, C. and Dal Bosco, A. 2002b. Meat quality of three chicken genotypes reared according to the organic system. Italian Journal of Food Science 14:401-412.

Culioli, J.; Touraille, C.; Bordes, P. and Girard, J. P. 1990. Carcass and meat characteristics of "label fermier" chickens. Archiv Fur Geflugelkunde 53:237-245.

Celik, S.; İnci, H. and Kayaokay, A. 2014. Japon Bıldırcınlarında Canlı Ağırlığın Yetiştirme Sistemleri Ve Cinsiyete Göre İncelenmesi. Turkısh Journal of Agricultural and Natural Sciences $1: 384-389$

Dal Bosco, A.; Mugnai, C.; Ruggeri, S.; Mattioli, S. and Castellini, C. 2012. Fatty acid composition of meat and estimated indices of lipid metabolism in different poultry genotypes reared under organic system. Poultry Science 91:2039-2045.

Dou, T. C.; Shi, S. R.; Sun, H. J. and Wang, K. H. 2009. Growth rate, carcass traits and meat quality of slow-growing chicken grown according to three raising systems. Animal Science Papers and Reports 27:361-369.

Fanatico, A. C.; Cavitt, L. C.; Pillai, P. B.; Emmert, J. L. and Owens, C. M. 2005. Evaluation of slower-growing broiler genotypes grown with and without outdoor access. Meat quality. Poultry Science 84:1785-90.

Fanatico, A. 2006. Alternative poultry production systems and outdoor access. NCAT Agriculture Specialist Published, 2006, ATTRA Publication $\neq$ IP300.

Fanatico, A. C.; Pillai, P. B.; Emmert, J. L. and Owens, C. M. 2007. Meat quality of slow- and fast-growing chicken genotypes fed low- nutrient or standard diets and raised indoors or with outdoor access. Poultry Science 86:2245-2255.

Grashorn, M. and Brose, K. 1997. Quality assurance in label programs for chicken meat. p.619-624. In: Proceedings of 13th European Symposium on the Quality of Poultry Meat. Poznan, Poland. World Poultry Science, Assoc. Polish Branch.

Herman, L.; Uyttendaele, M. and Heyndrickx, M. 2002. Bacterial safety of organically produced agricultural products. Working group of the scientific committee of the FAVV (SC Com 2001/35), Merelbeke, Belgium.

Hovi, M.; Sundrum, A. and Thamsborg, S. M. 2003. Animal health and welfare in organic livestock production in Europe: Current state and future challenges. Livestock Production Science 80:41-53.

Hughner, R. S.; McDonagh, P.; Prothero, A.; Shultz, C. J. and Stanton, J. 2007. Who are organic food consumers? A compilation and review of why people purchase organic food. Journal of Consumer Behavior 6:94-110.

Husak, R.; Sebranek, J. and Bregendahl, K. 2008. A Survey of commercially available broilers marketed as organic, freerange, and conventional broilers for cooked meat yields, meat composition, and relative value. Poultry Science 87:2367-2376.

Jiang, S.; Jiang, Z.; Lin, Y.; Zhou, G.; Chen, F. and Zheng, C. 2011. Effects of different rearing and feeding methods on meat quality and antioxidative properties in chinese yellow male broilers. British Poultry Science 52:352-358.

Küçükyılmaz, K.; Bozkurt, M.; Çatlı, A. U.; Çınar, M. and Bintaş, E. 2009. Organik ve konvansiyonel sistemde yetiştirmenin etlik piliçlerin karkas randımanı, karkas parçaları oranı ile kemik ölçüleri üzerine etkileri. 6. Ulusal Zootekni Bilim Kongresi. 24-26 Haziran 2009. 
Lei, S. and Van Beek, G. 1997. Influence of activity and dietary energy on broiler performance. Carcase yield and sensory quality. British Poultry Science 38:183-189.

Lewis, P. D.; Perry, L. J.; Farmer, R. R. and Paterson, L. 1997. Response of two genotypes of chicken to the diets and stocking densities typical of UK and Label Rouge production system: I. Performance, behavior and carcass composition. Meat Science 45:501-516.

Macrae, V.; Mahon, M.; Gilpin, S.; Sandercock, D.; Hunter, R. and Mitchell, M. 2007. A comparison of breast muscle characteristics in three broiler great-grandparent lines. Poultry Science 86:382-385.

Mikulski, D.; Celej, J.; Jankowski, J.; Majewska, T. and Mikulska, M. 2011. Growth performance, carcass traits and meat quality of slower-growing and fast-growing chickens raised with and without outdoor access. Asian-Australasian Journal of Animal Science 24:1407-1416.

Moujahed, A. R. and Haddad, B. 2013. Performance, livability, carcass yield and meat quality of Tunisian local poultry and fast-growing genotype (Arbor acres) fed standard diet and raised outdoor access. Journal of Animal Production Advances 3:75-85.

NRC - National Research Council. 1994. Nutrient requirements of poultry. 9th rev. ed. National Research Council National Academy Press, Washington, D.C. p.44-45.
Overbeke, I. V.; Duchateau, L.; De Zutter, L.; Albers, G. and Ducatelle, R. 2006. A comparison survey of organic and conventional broiler chickens for infectious agents affecting health and food safety. Avian Diseases 50:196-200.

Petek, M.; Gezen, Ş. Ş. and Alpay, F. 2004. İleri yaşlı kahverengi yumurtacı tavuklarda farklı yönetimsel faktörlerin yumurta verimi ve kalite özelliklerine etkisi. Uludağ Univ. Journal of the Faculty of Veterinary Medicine 23(1-2-3):55-58.

Söğüt, B.; İnci, H. and Şengül, T. 2011. Growth performance and carcass traits of broiler reared in conventional and organic condition. Asian Journal Animal and Veterinary Advances 6:992-1000.

Şahin, A.; Kutlu, H. and Görgülü, M. 2005. Organik tavukçuluk. IV. Ulusal Zootekni Bilim Kongresi. 01-03 Eylül 2005 Isparta: 278-285.

Yurtseven, S. and Şengül, T. 2009. Organik ve geleneksel yöntemlerle üretilen tavuk eti ve yumurtanın bazı kalite özellikleri, lezzet ve sağlık açısından karşılaştırılması. VI. Ulusal Zootekni Bilim Kongresi. 24-26 Haziran 2009 Erzurum: 94.

Wang, K. H.; Shi, S. R.; Dou, T. C. and Sun, H. J. 2009. Effect of a free-range raising system on growth performance, carcass yield, and meat quality of slow-growing chicken. Poultry Science 88:2219-2223. 